\title{
Berry Plants and Berry Picking in Inuit Nunangat: Traditions in a Changing Socio-Ecological Landscape
}

\author{
Noémie Boulanger-Lapointe ${ }^{1}$ (1) • José Gérin-Lajoie ${ }^{2,3} \cdot$ Laura Siegwart Collier $^{4} \cdot$ Sarah Desrosiers $^{1} \cdot$ Carmen Spiech $^{2,3}$. \\ Gregory H. R. Henry ${ }^{1}$ • Luise Hermanutz ${ }^{4}$ • Esther Lévesque ${ }^{2,3}$ • Alain Cuerrier ${ }^{5}$
}

Published online: 11 January 2019

(C) The Author(s) 2019

\begin{abstract}
Traditional food is central to Inuit culture and sense of identity. Recent changes in lifestyle, climate, and animal populations have influenced how people practice and experience activities on the land. We summarize the findings of 191 new and archived interviews addressing the continued relationships of Inuit to berries in the Canadian territories of Nunavut, Nunavik, and Nunatsiavut. Berry plants have been and remain widely used throughout the study area. Berry picking is an important cultural activity that contributes to spiritual, personal, and community wellbeing. In some regions, the availability of berries and accessibility to berry patches are threatened by climate change, recent increases in goose populations, as well as community development. Study outcomes suggest that berry picking should be considered in land-use planning since, alongside hunting and fishing, it is an activity that contributes to physical and mental health while being an important cultural practice across Inuit territories.
\end{abstract}

Keywords Arctic $\cdot$ Berry $\cdot$ Climate change $\cdot$ Pollution $\cdot$ Traditional food $\cdot$ Inuit Nunangat $\cdot$ Canada

\section{Introduction}

Traditional foods obtained through hunting, fishing, and gathering are an important part of Inuit diet (Searles 2016) as well as culturally meaningful and contributing to mental and physical health in contemporary Inuit communities (Loring and Gerlach 2009; Cunsolo Willox et al. 2012). The consumption

Electronic supplementary material The online version of this article (https://doi.org/10.1007/s10745-018-0044-5) contains supplementary material, which is available to authorized users.

Noémie Boulanger-Lapointe nboulangerlapointe@gmail.com

1 Department of Geography, University of British Columbia, Vancouver, BC V6T 1Z4, Canada

2 Département des sciences de l'environnement, Université du Québec à Trois-Rivières, Trois-Rivières, QC G9A 5H7, Canada

3 Centre d'études nordiques, Université Laval, Québec, QC G1V 0A6, Canada

4 Department of Biology, Memorial University, St. John's, NL A1B $3 \times 9$, Canada

5 Jardin botanique de Montréal, Institut de recherche en biologie végétale, Université de Montréal, 4101 rue Sherbrooke Est, Montréal, QC H1X 2B2, Canada of traditional foods is associated with healthier diets (Egeland et al. 2009) and is central to Inuit identity (Searles 2002), but urban living, as well as monetary and time constraints, make these resources increasingly difficult to access (Ford and Beaumier 2011). Among the numerous plants used by Inuit, berries are the most widely harvested today (Ootoova et al. 2001; Black et al. 2008; Nancarrow and Chan 2010).

Notes on plant usage are sporadically found in early explorers' accounts. While Boas (1901) reported berries mentioned in a number of stories and songs from Baffin Island and Hudson Bay, he otherwise widely dismissed the importance of berries. Birket-Smith (1929: 96) reports for the Central Arctic that "there is so little gathering of berries that it must almost be disregarded." Similarly, Mathiassen (1928: 207) noted for the Iglulik Inuit (now referred to as the Amitturmiut, Bennett and Rowley 2004) that "very little vegetable food is eaten; it has no part at all in the economy of the people." Stefansson (1914: 47) believed that in the western Arctic the "proximity to the vegetable-eating Indians of Alaska and not the richness of any given district determines the amount and variety of vegetables used." He also suggested that some groups might only recently have started picking cloudberries (Stefansson 1922). Porsild (1953) reported that although the amount of plant material used was small, northern residents make use of a large number of species. However, Porsild (1953: 16) also makes a direct connection between "the gathering of roots 
and berries $[\ldots]$ by women and children," the absence of agriculture, and the limited importance of plants for Inuit. The a priori assumption that plants are only important for societies involved in agriculture has also served to dismiss the importance of plants for other Indigenous groups in Canada (Turner and Turner 2008).

Interviews with Inuit Elders conducted in the second half of the twentieth and the early twenty-first century demonstrate that berry species have been widely used for food, medicine, fuel, and bedding (Kuhnlein and Soueida 1992; Cuerrier and Elders of Kangiqsujuaq 2011; Cuerrier and Elders of Kangiqsualujjuaq 2012; Cuerrier and Elders of Umiujaq and Kuujjuaraapik 2012). Berries have been identified as an important source of food in time of scarcity (Bennett and Rowley 2004) and berry picking has been linked to modern community wellbeing (Simard-Gagnon 2013; Cunsolo Willox et al. 2013; Kugluktukmiut Elders and Youth and Desrosiers 2016). Very few archeological investigations have looked into plant remains in the Arctic, but a study in northern Labrador found an abundance of berry seeds near human habitations dating from the eighteenth century (Zutter 2009).

Over the last century, Inuit have experienced major changes in their lifestyle and environment that have had direct impacts on land use and harvesting practices. Settlement and resettlement occurred at different times depending on the regions and individual families, but most Inuit had settled in communities by the mid-1960s (Tester and Kulchyski 1994). Settlement and the arrival of snowmobiles and all-terrain vehicles modified the way people travel on the land and hunt (Myers et al. 2005). At the same time, the effects of climate change were beginning to become apparent, with many regions experiencing milder winters as well as warmer and drier summers (Cunsolo Willox et al. 2013; Gérin-Lajoie et al. 2016) making transportation on the land, water, and ice increasingly difficult and unpredictable (Krupnik and Jolly 2010; Prno et al. 2011). Annual fluctuations in resource abundance have always occurred, but anthropogenic activities such as pollution and community expansion influence the availability and quality of traditional food (Abraham et al. 2005; Oostdam et al. 2005).

It is in this context that a major research effort was initiated during the International Polar Year (IPY) to understand the impact of environmental and climate change on Arctic tundra vegetation and the repercussions for people in the North (Henry et al. 2012). A special focus of the project was to document the ecology and the extensive knowledge and experience of berry plants passed from generation to generation of Inuit Qaujimajatuqangit (Karetak et al. 2017). A subset of the data collected as part of that project led to the publication of findings related to the knowledge and perception of climate change in Nunavik (Downing and Cuerrier 2011; Cuerrier et al. 2015; Rapinski et al. 2018a) and throughout the Canadian Arctic (Gérin-Lajoie et al. 2016). While other authors examined Inuit use of plants and berries, correcting the early literature that dismissed Inuit use of vegetation, this research provides a more comprehensive review of the cultural and social importance of berries as well as the constraints on availability allowing for an in-depth analysis and comparison of changes in berry use through time across Inuit Nunangat.

\section{Methods}

\section{Data Collection}

During IPY, interviews were conducted by the research teams in Kugluktuk (S. Desrosiers and J. Gérin-Lajoie), Baker Lake (J. Gérin-Lajoie and C. Spiech), Pond Inlet (J. Gérin-Lajoie), and Pangnirtung (J. Gérin-Lajoie) in Nunavut, Umiujaq (J. Gérin-Lajoie), Kangiqsujuaq (A. Cuerrier and J. GérinLajoie) and Kangiqsualujjuaq (A. Cuerrier and J. GérinLajoie) in Nunavik as well as in Nain, Nunatsiavut (A. Cuerrier and L. Siegwart Collier). Researchers chose field sites based on their ongoing involvement with the communities, geographic distribution as well as co-occurring scientific monitoring of berry productivity (Boulanger-Lapointe 2017). These interviews were the main source of information for this study and are hereafter referred to as "core interviews." Complementary interviews were conducted in Arviat in 2015 and archive material was gathered from the Oral History Project archives in Igloolik.

The core interviews were conducted between 2007 and 2011 with all necessary permits. Interviewees were identified from reports and personal communication with community representatives and local interpreters. Those selected were considered local knowledge holders because of the considerable amount of time they spent on the land whether this was ongoing or in the past. Sessions were conducted in the communities in Inuktitut with the help of an interpreter or directly in English or French depending on the interviewee's preference. The number of participants in each community depended on participants' availability during the researchers' stay in the community, knowledge of the research project, and desire to participate. A sufficient number of people were interviewed to draw recurring themes and observations for each community (i.e., between 9 and 24 interviewees per community) thus fulfilling the requirements of theoretical sampling (Gubrium et al. 2012). For this analysis, we used the interviews conducted with 138 people born between 1917 and 1965, 81 women and 57 men. Interview questions were both closed- and open-ended. Specific questionnaires varied somewhat between interviews although the objectives remained the same. During a typical interview, the interviewer(s) conducted a mapping exercise during which the participant(s) indicated their place of 
birth and the different locations where they lived, hunted, and gathered berries. The interview questionnaire was divided into five themes: 1) berries and berry picking activities, 2) abundance, distribution, and use of plants, 3) influence of climate on plants, 4) changes related to animals and 5) human factors related to climate change (see Cuerrier et al. 2015 for details).

In Arviat, interviews were conducted by local youth with the assistance of N. Boulanger-Lapointe. The interviews were first meant as a training and learning experience for the youth and as such vary in quality. Prior to the interviews, the youth and researcher discussed vocabulary associated with traditional food as well as potential questions. It was agreed that the interviews should touch on berries, their uses, where they could be found as well as on the animals that eat them. The youth were encouraged to discuss other subjects that might be linked to the Elders' responses. They conducted the interviews in Inuktitut with four Elders (three women and one man). Their conversations were later translated from the audio recordings. Since we did not reach the requirements of theoretical sampling for this community, the information provided by Elders from Arviat is used only as complementary data and is not included in summary tables.

In 2013, N. Boulanger-Lapointe searched the archives of the Oral History Project (OHP) in Igloolik for information on berries. The archive consists of transcripts of interviews conducted since the early 1980s with Elders from the area around Igloolik on a variety of subjects. A limited number of keywords were first selected and more were added until no more information on plants could be found. The following keywords were used to search for relevant interviews in the database: kigutangirnnait, kigutangirnaq, paurnngait, paurngait, paurngaqutillu, berry, berries, edible, medicinal, medicine and plant. The spelling of the Inuktitut words corresponds to the spelling used in the database. A total of 49 interviews were extracted from the database.

\section{Data Analyses}

The interviews from all communities were transcribed, when needed, and entered into QSR NVivo (QSR International Pty Ltd. 2016). The data were sorted using a thematic content analysis to extract and group the information related to the importance of berry plants and berry picking. The process of coding involved assigning both pre-determined and emergent categories (Brunet et al. 2014). All interviews were read through once and coded to extract major themes and read a second time to ensure that emergent themes were extracted from all interviews. The information was organized under the following themes: periods and methods of harvesting, recipes, beverages, medicinal preparations and properties, preservation techniques, roles of berry picking, sharing practices, material culture, consumption of berries by animals, and impacts of climate change and community development on berries.

We created a map showing the place of birth of participants of the core interviews and interviewees from Arviat using QGIS (QGIS Development Team 2017). Some informants were born in trading posts or communities, and these locations were easily identifiable. However, a majority of participants were born on the land and the location of their place of birth was based on the maps created during the interviews. It was possible to locate the place of birth of most of the informants (120 out of 142 participants). The missing geographical information largely came from Kangiqsujuaq and Kangiqsualujjuaq because maps were not systematically used during interviews in those communities.

The spelling and names of the different berry species were discussed with the interpreters from each community and when available validated from previous work by the authors (Appendix S1). Even though names have been validated using different sources, different spelling and pronunciation may be in use. Scientific names and authorities for plant species were validated using VASCAN (Brouillet et al. 2010+). For simplicity, common English names are used throughout the text. When we provide a translation for a word in English, this translation corresponds to the local dialect of the region discussed.

We created a map of the geographic distribution of the most commonly harvested berry species for each community where the core interviews were conducted using QGIS (QGIS Development Team 2017). We did not include the information from Arviat and Igloolik due to the small number of interviewees specifically discussing the subject of berries. The geographic distribution of each berry species is based on Porsild and Cody (1980). A berry species was deemed "commonly harvested" when three or more interviewees from one community mentioned harvesting it.

Finally, we summarized in tables the information gathered under the themes "recipes," "beverages," and "medicinal preparations and properties." For each theme, we listed all the recipes or preparations, assigned them a relative frequency (rare, occasional, common) and listed the community of residence of the interviewee. Because each interviewee was not necessarily asked the same questions and questions were frequently worded differently due to different interpreters and the semi-structure nature of the interviews, the relative frequency should not be taken as an absolute representation of local knowledge of berry plants. Instead, they serve to demonstrate the widespread uses of berry plants and provide indicators of local preferences and ethnobotanical knowledge. 


\section{Results and Discussion}

Interviews provided information on a wide range of subjects linked to personal history, harvesting activities, and the environment. For this analysis, we focused on the cultural and social importance of berry picking as well as ethnobotanical knowledge and quality and availability of berries. We present an overview of these topics through time and across regions.

A majority of informants were elderly and due to reduced mobility seldom went out on the land anymore. Younger people interviewed were active on the land and recognized as very knowledgeable of the environment by their community. Informants were born and grew up throughout the three Canadian Arctic territories (Fig. 1) and moved into a community in their early childhood or later in their life. For a number of them, this transition was gradual with a period during which they lived on the land for parts of the year. All interviewees now live permanently in communities.

Informants knew and harvested most berry species present in their area (Figs. 2 and 3). They often had an intimate knowledge of their ecology although some common and local names referred to more than one species (Appendix S1). The most commonly harvested were blueberries (Vaccinium uliginosum L. and V. caespitosum Michx.), crowberries or blackberries (Empetrum nigrum L.), cranberry, lingonberry, partridgeberry or redberry (Vaccinium vitis-idaea L.), and cloudberries or bake apple (Rubus chamaemorus L.). Bearberries (Arctous rubra Rehder \& Wilson Nakai and A. alpina L. Nied.), although present throughout most of the areas, were only commonly harvested by Kugluktukmiut. Local raspberry species (Rubus arcticus L. and Rubus idaeus L.) were harvested in small amounts near Umiujaq, Nain, and Kangiqsualujjuaq. Marshberries (Vaccinium oxycoccos L.), skunk currants (Ribes glandulosum L.), and squashberries (Viburnum edule (Michx.) Raf.) were harvested by a small number of people in the vicinity of Nain. These three berry species are also present near Kangiqsualujjuaq, Umiujaq, and Kuujjuarapik although informants did not mention them. Ethnobotanical research conducted by Cuerrier and Elders of Kangiqsualujjuaq (2012) as well as Cuerrier and Elders of Umiujaq and Kuujjuaraapik (2012) indicated that some residents know about these species, but they are not commonly harvested because of their low abundance. The different stages of development of the fruit as well as the different parts of the plant have specific names that were known by some of the informants. These would however need further investigation to find appropriate pronunciation and spelling for each region.

Berries are harvested throughout the study area and preferred species vary according to personal taste. While the number of berry species declines at higher latitudes, the density of berries is highest in subzone D (Walker

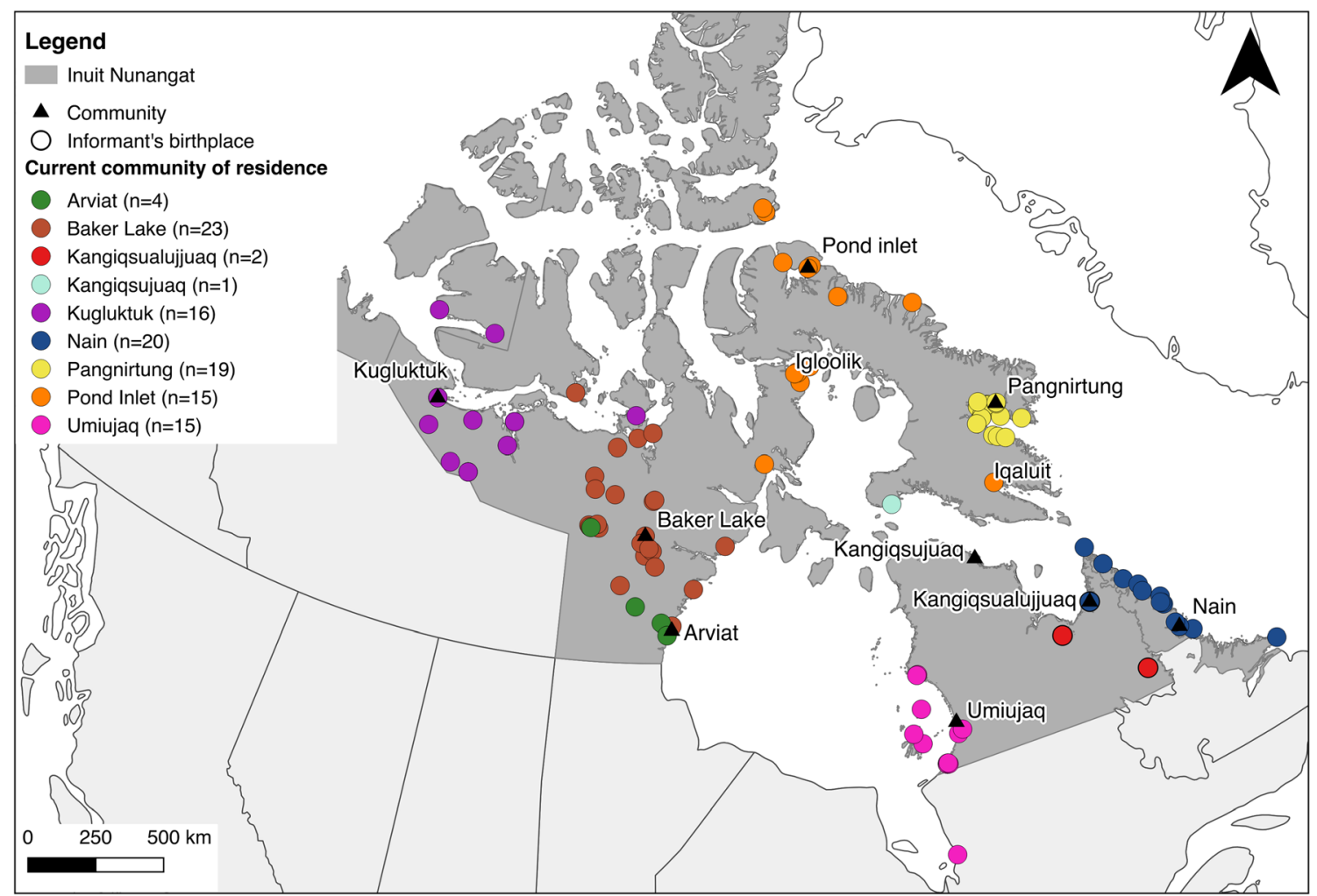

Fig. 1 Birthplace of informants from the core interviews as well as interviewees from Arviat along with the location and names of the communities where the interviews were conducted throughout Inuit Nunangat 
Fig. 2 Most common berry species in Inuit Nunangat: a bearberry (Arctous alpina, picture taken in the fall), b crowberry (Empetrum nigrum), c blueberry (Vaccinium uliginosum), d cranberry (Vaccinium vitis-idaea) and e cloudberry (Rubus chamaemorus)

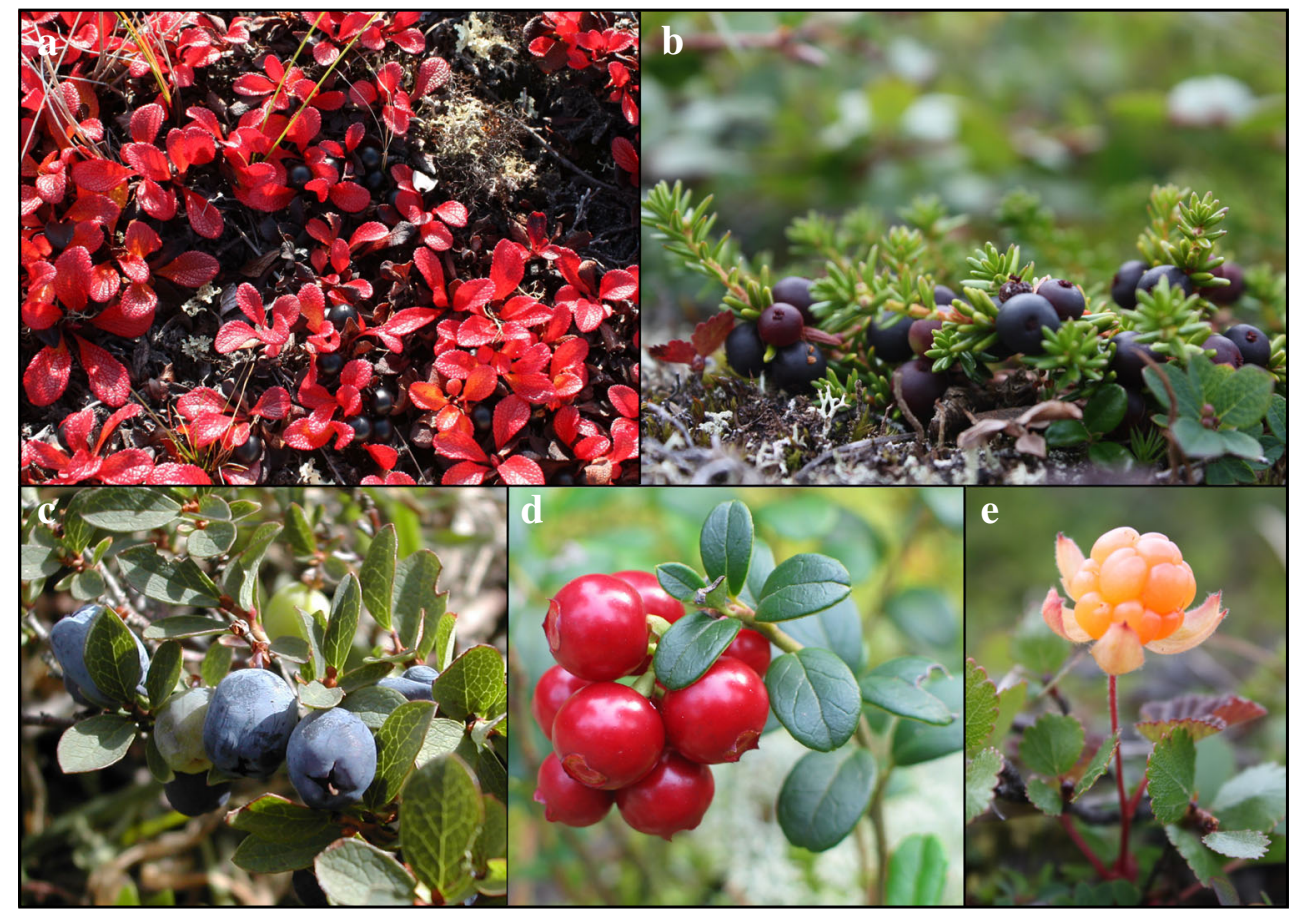

et al. 2005) where Kangiqsujuaq and Pangnirtung are located (Fig. 3; Boulanger-Lapointe 2017). Berries are especially important for people in Umiujaq and Nain, two southern communities with a wide variety of species and productive patches, but also in Pangnirtung, where only four species are found in abundance.

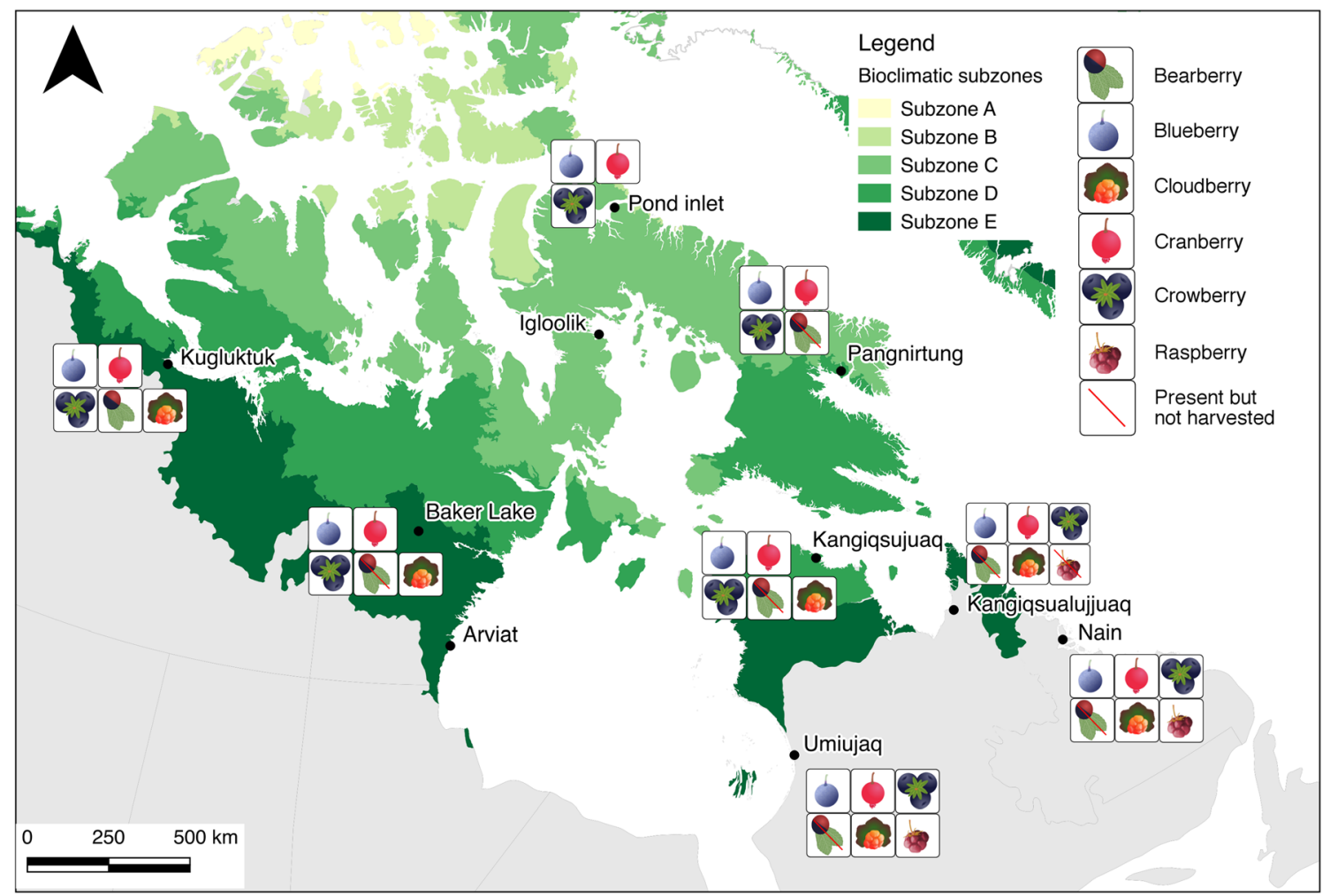

Fig. 3 Bioclimate subzones: Subzone A- cushion forbs, moss and lichens; subzone B- prostrate dwarf shrubs; subzone C- hemi-prostrate dwarf shrubs; subzone D- erect dwarf shrubs; subzone E- low shrubs (Walker et al. 2005). Kangiqsualujjuaq, Nain and Umiujaq are located in the forest-tundra ecotone. Presence of the six main berry species: unless otherwise mentioned, all berry species are commonly consumed where present. The two bearberry species are represented by the same logo 


\section{Ethnobotanical Knowledge}

\section{Timing and Methods of Harvesting}

Few items of material culture are specifically associated with berry picking; a strainer, used to collect berries during the winter, was mentioned by a small number of informants while a minority of people used berry pickers, a rake-like tool with a short handle. First Nations in montane areas of British Columbia used to make a similar tool for berry picking (Turner et al. 2011), although none of the informants recalled using such instruments in the past. Berries are collected in buckets, barrels, used coffee tins, flour bags, or whatever container is available. In the past bags made out of caribou or seal-skin were used.

People plan trips specifically to go berry picking, usually near their cabin. Most people pick berries during the peak in productivity at the end of the summer before the first frost. Cranberries are also harvested after the first frost or in the spring as they become sweeter after freezing. In the past, berries were commonly harvested throughout the year when they ripen, under the snow in winter or right after snowmelt in spring. One informant described how they would put markers on the land before the snow fell in order to find the best patches during the winter:

During the winter $[\ldots]$ my mother would pick blackberries under the snow. Before it snowed and the land would be freezing, we would build small inuksuit near the crowberries. It's easier to pick in the winter because they are frozen and don't break easily.

- Elijah Panipakoocho, Pond Inlet

Although many interviewees mentioned that berries cannot be preserved during the winter when they were living on the land "because they had no freezer," preservation techniques were described by others. Berries are stored in the ground a variety of containers such as hide pouches, fish swim bladders, and caribou stomachs as well as flour and sugar bags, metal tins, and clothes. Berries may be cached with meat or by themselves in cracks covered with moss, on a steep hill between rocks or under the sand close to the beach. In Nain, some people recalled leaving berries in bags hanging from the trees. Mixing berries with animal fat or caribou marrow helps to preserve the fruits and will later provide a more wholesome meal.

\section{Food Preparations}

Most people eat berries raw, both while picking and immediately after returning to the community. Blueberries and crowberries are often mixed. Some people mentioned being warned that they should not eat too many berries, especially crowberries, on an empty stomach because it may cause stomach ache and in extreme cases death, in particular after a period of fasting or famine. Throughout the Arctic, berries are commonly mixed with fat, blubber, fish, and other fruits or vegetables, and the different preparations are referred to in English as "Eskimo or Inuit pudding/ice cream" (Oswalt 1957; Andre and Fehr 2001; Joamie and Ziegler 2009; Appendix S2, Table S1). Crowberries are most often used in food preparations although cranberries or a mixture of crowberries and blueberries are also used. Fresh crowberry leaves can be eaten with oil before the plant produces fruits. Blueberry leaves may be eaten fresh and are preferentially harvested when the fruits are turning red. The tip of blueberry roots can also be eaten fresh. Less common recipes combined berries with seal brain and blood as well as with ptarmigan skin and the intestines of caribou and hare.

A modern version of the pudding involves mixing lard and/ or cooking oil instead of wild animal fat (Appendix S2, Table S2). Berries may also be used in bannock or muffin dough. They are eaten with a variety of sweeteners, such as sugar, molasses, ice cream, and condensed milk. They are also made into jam. A number of elderly people mentioned that they like their berries raw or prepared the traditional ways while younger people prefer using store-bought ingredients for recipes with berries.

Beverages may be prepared from the leaves, stems, and fruits of berry plants (Appendix S2, Table S2), generally more often when living on the land although some informants still use cooked cranberries for food and medicine. It is unclear if Inuit were drinking tea before contact with Euro-Canadians (Birket-Smith 1929), however this practice seems to have become widespread and very important for some of the informants.

What we really depended on were bearberry and prickly saxifrage leaves, they were really part of our survival for tea. -Inursiq Nashalik, Pangnirtung

Some regional patterns emerged regarding the different food preparations and uses for the fruits and vegetative parts of berry plants. Only in Umiujaq did interviewees mix berries with cooked fish and only in Nain did they combine them with fish liver. Similarly, the leaves of cloudberries were used for tea only by informants from Baker Lake and the leaves of blueberries were harvested for consumption only in Pangnirtung. Local availability of certain ingredients could explain some but not all of these differences. We know that food preparations and uses reported here represent a subset of local knowledge of berries in Inuit Nunangat due to the broad scope of the interviews (i.e., interviews were not solely focused on ethnobotanical 
knowledge). Previous work by Cuerrier and Elders of Kangiqsujuaq (2011), Kangiqsualujjuaq (2012), and Umiujaq and Kuujjuaraapik (2012) suggests that in-depth ethnobotanical interviews may gather a greater wealth of information. Nevertheless, the few mentions of other recipes, notably including parts of the animals not sought after by the younger generation, such as intestines and brain, may be associated with a diminution in the diversity of traditional food consumed and the erosion of the knowledge associated with these ingredients (Beaumier et al. 2015).

\section{Medicinal Uses}

Berries and other parts of the plants are known for their medicinal properties and may be used to cure specific afflictions (Appendix S2, Table S3). Pharmaceutical studies have shown that berry species are rich in antioxidants that can ameliorate metabolic disorders such as obesity and type 2 diabetes (see e.g., Määttä-Riihinen et al. 2004; Taruscio et al. 2004; Ogawa et al. 2008; Harris et al. 2014). These properties were well known by Cree healers (Fraser et al. 2007), although not usually mentioned by our informants. Inuit notions of health are holistic, and, contrary to western medicine, do not focus on the absence of illness or injuries (Ootoova et al. 2001; Rapinski et al. 2018b). This was reflected by a number of informants who stated that berries, like other traditional foods, were good for your health without identifying specific medicinal purposes.

The crowberry plant was used to make tea, the whole plant. [...] It is very nutritious and helps the body in terms of health. It gives you certain nutrients. -Taukie Qappik, Pangnirtung

Health surveys revealed that food insecurity and the consumption of poor quality food are important issues in the Canadian Arctic (Huet et al. 2012) of which our informants were very much aware (Kuhnlein and Soueida 1992; Fediuk et al. 2002).

\section{Other Uses of Berry Plants}

Crowberry plants were used throughout the study area as a fuel; the smoke may repel insects and be used to smoke meat. To a lesser extent, they may be used to insulate bedding by placing plants on the ground underneath a hide. Some interviewees from Baker Lake who lived and travelled to further south mentioned smoking bearberry leaves when they were living on the land and ran out of cigarettes. It is however unclear if they were referring to Arctostaphylos uva-ursi a boreal species, also commonly called bearberry, and often smoked by First Nations (Thornton 1999).

The ethnobotanical knowledge reported supports findings from regional studies conducted in Alaska (Oswalt 1957; Ager and Ager 1980), the Northwest Territories (Andre and Fehr 2001), Nunavut (Ootoova et al. 2001; Joamie and Ziegler 2009), Nunavik (Cuerrier and Elders of Kangiqsujuaq 2011; Cuerrier and Elders of Kangiqsualujjuaq 2012; Cuerrier and Elders of Umiujaq and Kuujjuaraapik 2012) and Nunatsiavut (Cuerrier and Hermanutz 2012; Downing et al. 2013), and shows this knowledge is widespread in Inuit communities across Canada. The different uses and roles of berry plants evolved through time and corresponded to the different needs associated with life on the land and in the community (Fig. 4). We represented the time "On the land" within the time "In the community" because this time is part of Elders' stories and informs their teachings. It is also central to Inuit sense of identity and when spending time on the land, people are more inclined to harvest available resources, including berries. Historically, most of the same uses and functions persisted while their relative importance changed. The transition observed in term of the uses and functions of berry plants can also be extended to the social and cultural value of berries and berry picking (Fig. 4).

\section{Social and Cultural Value of Berries}

Throughout the interviews, informants highlighted the reasons why they go berry picking. These were numerous and matched reports for the Gwich'in people in the Northwest Territories (Parlee and Berkes 2005) and Alaska native communities (Flint et al. 2011): 1) berries are tasty and nutritious, 2 ) it is an occasion to spend time on the land, 3) it is an opportunity to spend time with family and friends, 4) it is part of their culture, 5) it contributes to sharing practices, and 6) it helps maintain a spiritual relationship to the land.

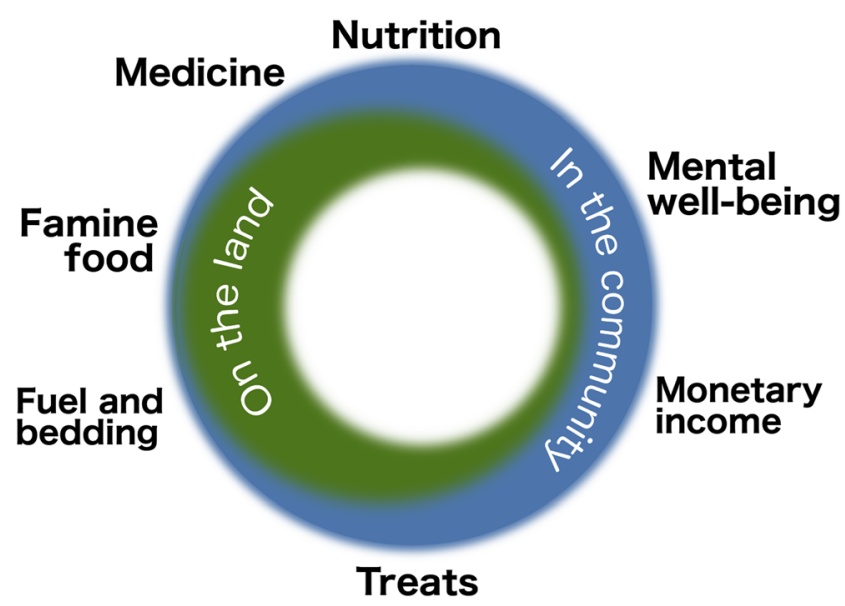

Fig. 4 Evolution of the uses and functions of berry plants and berry picking through time represented by the time "on the land" and "in the community" 


\section{Personal Well-Being}

Interviewees described how berry picking is calming and an opportunity to get away from stresses of the community. Berry picking trips contribute to mental health (Cunsolo Willox et al. 2013) and provide "psychological goods" (Dowsley 2015) that may be acquired informally through a family trip, alone, in small groups, or, more formally, through land-based counselling and "healing" trips. While many go berry picking with their spouse, some informants discussed how berry picking is an opportunity for women to be alone or with their younger kids away from community.

I like going berry picking not just to get big pails of berries but because you are out alone. [...] Calm and just enjoying yourself. [...] Small children, they usually come along but you don't have to worry that they will go out of sight. They are more free, it's good therapy. -Anonymous

Some also described how exciting it is to find a good berry patch:

I remember, I was chasing a caribou. I was tracking it, chasing it and it ended up going to this little ground. I found cloudberries there and I forgot about the caribou. I took my shirt off and started picking. After I finished picking it was really heavy to carry. They were so tasty. -John Ohokak, Kugluktuk

When living on the land with limited or no access to storebought food, berries brought a welcome change in a diet based on meat and fat. Moreover, berries may save lives in times of scarcity and famine. Indigenous groups throughout North America used plants such as berries as famine food because they were a reliable resource when hunting and fishing failed (Turner and Davis 1993; Thornton 1999). The Arctic has a shorter growing season and less productive vegetation, but plants still played an important role during episodes of famine.

That summer the caribou were scarce so we would have to go without meat for extended periods of time so we had to resort to plant[s] and vegetation such as airaq [roots of plants] and berries. -Rebecca Irngaut, Igloolik

\section{Community Well-Being and Sharing Practices}

Berry picking is very much a family activity and interviewees remembered picking berries at a young age with their mother. Work by Sarah Desrosiers with middle and high school students in Kugluktuk showed that berry picking is still very much appreciated by youth and some described it as an opportunity to spend time with their family (Kugluktukmiut Elders and Youth and Desrosiers 2016); similar sentiments were also expressed in Nain (Cuerrier et al. 2012). Although a number of men interviewed were active berry pickers, many described how during a family trip in the fall, women and children may be dropped at a good berry picking patch for the day while men go caribou hunting or fishing.

Berries are shared with family and friends and to a lesser extent Elders outside the family and the community as a whole (e.g., community freezer). Informants willingly shared the locations of berry picking patches and pointed out on the map general areas and specific locations close and far from the community that they may access by all-terrain vehicle, boat, or on foot. Through informal discussion, we understood that berries located close to a cabin "belong" to the owner. However, very few people were protective of berry patches located away from cabins with the exception of informants from Umiujaq and Nain where it was repeatedly mentioned that the best berry picking spots are kept secret.

Parlee and Berkes (2006) documented common property management practices and rules related to the access of berry picking patches for the Gwich'in in the vicinity of Fort McPherson, NWT. They found rules related to the availability of certain berries as well as traditional family patches. Similarly, Karst and Turner (2011) described how residents of Charlottetown in southern Labrador harvest cloudberries in areas that they used to visit with their parents. Only one interviewee from Nain mentioned that he kept some of his best berry picking spots secret because they were particularly productive ones his family harvested in the past. In Umiujaq, informants who kept their berry patches secret did not mention that these areas were traditionally used by their family although the question was not specifically asked. Differences between Inuit and other Indigenous groups in Canada may be related to the recent history of Inuit relocations. However, it may also have to do with a certain relationship to the land where slow vegetation growth and long regeneration time oblige people to move often and prevent them from re-using a certain area for a while. Bennett and Rowley (2004: 383384) reported how traditional beliefs associated with land use required people to move in order for the land to replenish and "cool down" after being used for some years. If a camp is occupied for too long the land becomes "hot and dangerous." On the other hand, low population density may have meant there were enough berries for everyone and it was not worth the effort to protect patches (Thornton 1999). Finally, it may also be linked to local history and relationship, both historical and in these specific studies, between local communities and researchers.

Elderly people from Kugluktuk remembered using berries as a trading good when they did not actively participate in the wage labour market. Otherwise, only in Nain did informants 
often mention that berries are now commonly sold to community members, often to those in the wage economy. None of the interviewees expressed concerns about the exchange of berries for money and some noted that they may buy berries when they are unable to pick themselves. Even if the subject was discussed only by residents of Nain, our observations across Inuit Nunangat suggest that this practice is slowly becoming more common. It is notably common to see posts of people wanting to buy berries on the community's Facebook page. Moreover, suvaliq a much sought treat, is sometime sold at the entrance of the grocery store in Nunavik. Informants did not express concern about this practice, although they were not asked directly. However, this topic may be of special interest as the exchange of traditional food for money is a growing concern in the Canadian Arctic and Alaska (Parlee and Berkes 2006; Karst and Turner 2011; Kellogg et al. 2011) where it is believed to disrupt traditional food sharing systems (Searles 2002; Kishigami 2004).

\section{Cultural and Spiritual Dimensions}

Berries are shared during community feasts and celebrations such as Christmas. Residents of Umiujaq discussed their participation in the annual Blueberry festival, an event appreciated by locals and which attracts people from other communities. Even though people now harvest berries during a short period of time in the summer and fall, they still consider it an important resource and as such, it is part of life and conversations throughout the year.

Even today [March $6^{\text {th }}$ ] some women are thinking about the berries that will grow this summer wishing for rain and sunshine. -Juusipi Nappaaluk, Kangiqsujuaq

Berry picking is valued as a cultural activity and a berry picking trip may be planned even if few berries are expected to be found. When living on the land, travels were planned according to animal availability; berries were generally picked while travelling or in the vicinity of the camp. This idea of picking berries "on the way to" or near cabins and the community is still very important, but a number of people also talked about making dedicated trips that seem associated to the cultural value of berries and their place in contemporary Inuit communities and lifestyle.

Finally, little is known about the symbolic place of berries for Inuit. Boas (1901) noted a story where an Angakok (an Inuit shaman) stopped a monster by putting a berry patch in his way; the monster could not help but stop to eat the berries. Similarly, informants reported that you should not eat the berries from a place where there never used to be any because they will make you sick. The most reported example is referred to as the "Toxic berries" event that occurred in 1943 when the Qarmaarjuit outpost community situated in the Pond Inlet area largely perished. It is a popular belief that it was the berries they ate at Qinniqtut, on their way back from walrus hunting, that caused their death and people nowadays still avoid picking berries on the site (Gérin-Lajoie and Lévesque 2011). Moreover, berries, like other non-human agents (see among others Nadasdy 2007; Watson and Huntington 2008), have a salient presence on the land and must be treated with respect (Thornton 1999). In that sense, some interviewees were taught that berries will not grow well if they are not harvested. The reciprocal relationship of people and plants, and the responsibility of wild plant harvesters has been discussed for other Indigenous groups in North America (Turner 2005) but rarely mentioned for Arctic regions.

\section{Factors Affecting the Quality and Availability of Berries}

Inuit are very much aware of annual fluctuations in climate, animal populations, and plant productivity. These have always occurred and people have had to adapt to survive. In the last century, northern residents noticed that climate and environmental changes put increasing pressure on the land with impacts on the productivity, availability, and accessibility of berry patches (Kellogg et al. 2010; Flint et al. 2011).

\section{Community Development and Pollution}

Informants often contrast their life on the land with living in the community, which requires travel to collect berries, costing money and becoming more difficult with age and reduced mobility.

There is an area down beyond this map where I would prefer to collect berries but we don't go often because it is so far and it would cost a lot of money. -Leopa

Akpalialuk, Pangnirtung

Some communities have berry patches close to residential areas, but infrastructure, including houses, sewage lagoons, dumps, and airports as well as motorized traffic and dust from the roads may reduce their quality and productivity. Some also fear the effect of atmospheric pollution due to local sources such as dump fires and global pollution from acid rain. Some informants believe that pollution is changing the taste of berries and others no longer pick in areas directly affected by pollution.

Constraints on the accessibility and availability of berries vary by region. Concerns about the impact of mining activities were localized and came from residents of Baker Lake and Nain, both located near active mines. Similarly, residents of Kugaaruk, Nunavut, believed that mining exploration affected 
the taste of animals (Nancarrow and Chan 2010). While exploration permits usually take into account impacts on wildlife, they rarely consider potential negative effects on berry patches. In a conversation with the person in charge of issuing exploration permits for mining companies in Nunavut, we were asked if it would be possible to document berrypicking patches in order to protect them against exploitation or if such an initiative would be met with criticism (Boulanger-Lapointe, unpubl. data), highlighting the lack of written accounts and the consequent difficulties for land use planners to integrate berry conservation into their day-to-day decisions. In Nunatsiavut, community mapping exercises were conducted to pinpoint those areas of importance for community harvesting (R. Laing, pers. comm. to Hermanutz) and such initiatives could be carried out in order to protect berry patches elsewhere.

\section{Consumption and Trampling by Animals}

Berry pickers have to share patches with a number of animal species. Informants explained how all bear species (black, grizzly, and polar bears), fox, wolf, geese (greater snow, lesser snow, and Canada geese), ground squirrel, hare, partridge, ptarmigan, raven, seagull, and a number of small birds eat berries. Caribou are not usually believed to eat berries, although trampling by large herds may reduce berry production. Among all those species, informants expressed concerns only about geese. Goose populations have been increasing in the last 50 years due to agricultural changes that provide a readily abundant food source during migration and wintering (Abraham et al. 2005). Although drastic population management measures have been taken, they are still considered overabundant (Koons et al. 2014). Migrating geese were found to eat $30-60 \%$ of the annual crowberry production on the Alaska Peninsula in the fall (Hupp et al. 2013). However, the consumption of berries is much lower in areas not directly located on the southward migration path (Boulanger-Lapointe 2017). Nevertheless, the effect of geese on berry availability was strongly felt in most of the communities where the core interviews were conducted.

There is a lot more Canada geese now. Even when we try to go berry picking, where we know that there usually are berries, if the geese have been there then the berries are usually gone. Some women hate Canada geese. Canada geese they seem to know what's better too. Like us, they intend to pick the better tasting ones. Both the women and the Canada geese want to eat those berries, they are in competition. -Pauloosie Veevee, Pangnirtung

\section{Recent Climate Change}

In Alaska, climate change or climate fluctuations from yearto-year were identified as the main threats to berries (Kellogg et al. 2010). Informants in our study presented mixed opinions on the effect of climate change on berry productivity. A diminution in snowfall and summer precipitation was widely observed in Nunavut and some attributed a change in the taste of berries to drier conditions (Gérin-Lajoie et al. 2016). Downing and Cuerrier (2011) as well as Cuerrier et al. (2015) and Gérin-Lajoie et al. (2016), using data from the core interviews, documented local observations of the increase in shrub cover associated with recent climate change (Tremblay et al. 2012; Myers-Smith et al. 2015). They showed that the increase in height and cover of erect shrubs constrains movements on the land and reduces the accessibility of berry patches. It is however unclear from our interviews if the increase in shrub height and cover have a direct negative impact on berry productivity. In some instances, shrubs are perceived to diminish berry productivity while in others, like during a warm and dry summer, they may provide shade and thus have a positive influence on the quality of the berries. However ecological studies conducted in Umiujaq (Lavallée 2013; Lussier 2016) and Nain (Siegwart Collier unpublished data) showed that the cover and productivity of berry species usually diminished under erect shrubs suggesting that the impact might be largely negative.

\section{Conclusion}

This research demonstrates that berry species were and remain important for Inuit in Canada. Although berries ripen within a narrow window, they are and were preserved for later use and harvested throughout the year. Berries and berry picking confer physical, mental, and community wellbeing in Inuit communities being a family activity that contributes to cultural preservation and connection with the land while still being one of the most affordable harvesting activities. When berry patches are present near communities, berry picking can easily be done after a day at work and does not require special equipment. Berry picking is an easy way to escape life in the community and connect with the land while providing nutritious food. However, increasing pressure from community development, extended impact of pollution, overabundant goose populations as well as recent climate change may reduce the quality, availability, and accessibility of patches nearby communities.

Finally, it became obvious during the course of this project that documenting the cultural importance of berry plants and berry picking not only provided a better understanding of Inuit culture, but also had direct repercussions on land use planning 
practices. If productive berry patches around the community were documented and mapped, they could be protected from community and industrial development in order to facilitate continued access to this important traditional food. In a context of rapid social and environmental changes in the Arctic, this research will provide a much-needed written account of the widespread cultural importance as well as the barriers to the accessibility of berry picking for Inuit in Canada.

Acknowledgements Very special thanks are due to all participants with whom we conducted interviews (Appendix S3). It is with great respect that we thank them for sharing with us their knowledge and experience. We also express our gratitude to the interpreters for their essential role in assisting us with the interviews: Lucassie Tooktoo, Pasha Arngak, Mary Adams, Mary Annanack, Rita Annanack, Annie Baron, Harriet Etok, Charlotte Morgan, Jonah Kilabuk, Eric Joamie, Rita Nookiguak, Domina Koonark, Joanna Innualuk Kunnuk, Elisapie Kyak, Lucy Quassa, Vera Avaala, Hattie Mannik, Thomas Mannik, Doris Elatiak, and Wilson Jararuse. We are grateful to all the people who warmly hosted us in their home, to the staff from the Archives of the Oral History Project in Igloolik, to Riley McPherson for graphic design as well as to Nicholas Coops, Susan Rowley, Jennifer Williams, and Amy Angert for comments on the manuscript.

Funding This study was funded by the Canadian International Polar Year program for the project Climate Change Impacts on Canadian Arctic Tundra (IPY-CiCAT), ArcticNet, the Natural Sciences and Engineering Research Council of Canada (NSERC), the Northern Scientific Training Program (NSTP) and the W. Garfield Weston Foundation.

\section{Compliance with Ethical Standards}

Conflict of Interest The authors declare that they have no conflict of interest.

Informed Consent Prior informed consent was reached before any interview started as per the ethics permit: Climate change impacts on Canadian Tundra (CiCAT) (CER-07-124-07.18), The Arctic Berry Project, Arviat (H13-00420) and Nain (ICEHR2008/09-131-SC).

Open Access This article is distributed under the terms of the Creative Commons Attribution 4.0 International License (http:// creativecommons.org/licenses/by/4.0/), which permits unrestricted use, distribution, and reproduction in any medium, provided you give appropriate credit to the original author(s) and the source, provide a link to the Creative Commons license, and indicate if changes were made.

Publisher's Note Springer Nature remains neutral with regard to jurisdictional claims in published maps and institutional affiliations.

\section{References}

Abraham, K. F., Jefferies, R. L., and Alisauskas, R. T. (2005). The Dynamics of Landscape Change and Snow Geese in MidContinent North America. Global Change Biology 11(6): 841855. https://doi.org/10.1111/j.1365-2486.2005.00943.x.
Ager, T. A., and Ager, L. P. (1980). Ethnobotany of the Eskimos of Nelson Island, Alaska. Arctic Anthropology 17(1): 26-48.

Andre, A. and Fehr, A. W. (2001). Gwich'in Ethnobotany: Plants Used by the Gwich'in for Food, Medicine, Shelter and Tools, Gwich'in Social and Cultural Institute and Aurora Research Institute, Inuvik, Northwest Territories.

Beaumier, M. C., Ford, J. D., and Tagalik, S. (2015). The Food Security of Inuit Women in Arviat, Nunavut: The Role of Socio-Economic Factors and Climate Change. Polar Record 51(260): 550-559.

Bennett, J. R. and Rowley, S. (2004). Uqalurait. An Oral History of Nunavut, McGill-Queen's University Press, Montreal and Kingston.

Birket-Smith, K. (1929). The Caribou Eskimos: Material and Social Life and Their Cultural Position, Gylendal, Copenhagen.

Black, P. L., Arnason, J. T., and Cuerrier, A. (2008). Medicinal Plants Used by the Inuit of Qikiqtaaluk (Baffin Island, Nunavut). Botany 86: $157-163$.

Boas, F. (1901). The Eskimo of Baffin Land and Hudson Bay: from Notes Collected by Capt. George Comer, Capt. James S. Mutch, and Rev. E. J. Peck, Order of the Trustees, New York.

Boulanger-Lapointe, N. (2017). Importance of Berries in the Inuit Biocultural System: A Multidisciplinary Investigation in the Canadian North, $\mathrm{PhD}$ thesis, University of British Columbia.

Brouillet, L., Coursol, F., Meades, S. J., Favreau, M., Anions, M., Bélisle, P. and Desmet, P. (2010+). Vascan, the Database of Vascular Plants of Canada. http://data.canadensys.net/vascan/. Accessed July 2017

Brunet, N. D., Hickey, G. M., and Humphries, M. M. (2014). Understanding Community-Researcher Partnerships in the Natural Sciences: A Case Study from the Arctic. Journal of Rural Studies 36: 247-261.

Cuerrier, A. and Elders of Kangiqsualujjuaq (2012). The Botanical Knowledge of the Inuit ofKangiqsualujjuaq, Nunavik, Institut culturel Avataq, Montreal, Quebec.

Cuerrier, A. and Elders of Kangiqsujuaq (2011). The Botanical Knowledge of the Inuit of Kangiqsujuaq, Nunavik, Institut culturel Avataq, Montreal.

Cuerrier, A. and Elders of Umiujaq and Kuujjuaraapik (2012). The Botanical Knowledge of the Inuit ofUmiujaq and Kuujjuaraapik, Nunavik, Institut culturel Avataq, Montreal, Quebec.

Cuerrier, A. and Hermanutz, L. (2012). Our Plants... Our Land. Plants of Nain and Torngat Mountains Basecamp and Research Station (Nunatsiavut), Nunavik Publications, Westmount.

Cuerrier, A., Downing, A., Johnstone, J., Hermanutz, L., CollierSiegwart, L., and Elders and Youth Participants of Nain and Old Crow (2012). Our Plants, Our Land: Bridging Aboriginal Generations through Cross-Cultural Plant Workshops. Polar Geography 35(3-4): 195-210.

Cuerrier, A., Brunet, N. D., Gérin-Lajoie, J., Downing, A., and Lévesque, E. (2015). The Study of Inuit Knowledge of Climate Change in Nunavik, Quebec: A Mixed Methods Approach. Human Ecology 43(3): 379-394.

Cunsolo Willox, A., Harper, S. L., Ford, J. D., Landman, K., Houle, K., Edge, V. L., and Rigolet Inuit Community (2012). "From This Place and of This Place": Climate Change, Sense of Place, and Health in Nunatsiavut, Canada. Social Science \& Medicine 75(3): 538-547. https://doi.org/10.1016/j.socscimed.2012.03.043.

Cunsolo Willox, A., Harper, S. L., Edge, V. L., Landman, K., Houle, K., Ford, J. D., and Rigolet Inuit Community Government (2013). The Land Enriches the Soul: On Climatic and Environmental Change, Affect, and Emotional Health and Well-Being in Rigolet, Nunatsiavut, Canada. Emotion, Space and Society 6: 14-24.

Downing, A., and Cuerrier, A. (2011). A Synthesis of the Impacts of Climate Change on the First Nations and Inuit of Canada. Indian Journal of Traditional Knowledge 10(1): 57-70.

Downing, A., Cuerrier, A., Hermanutz, L., Courtenay, C., Fells, A. and Siegwart Collier, L. (2013). Community of Nain, Labrador: Plant 
Uses Booklet, Institut de Recherche en Biologie Végétale \& Memorial University, Montréal, St-John's.

Dowsley, M. (2015). Identity and the Evolving Relationship between Inuit Women and the Land in the Eastern Canadian Arctic. Polar Record 51(260): 536-549.

Egeland, G. M., Charbonneau-Roberts, G., Kuluguqtuq, J., Kilabuk, J., Okalik, L., Soueida, R. and Kuhnlein, H. V. (2009). Back to the future: using traditional food and knowledge to promote a healthy future among Inuit. In Kuhnlein, H. V., Erasmus, B., and Spigelski, D (eds), Indigenous Peoples' Food Systems: The Many Dimensions of Culture, Diversity and Environment for Nutrition and Health. Food and Agriculture Organization of the United Nations Centre for Indigenous Peoples' Nutrition and Environment, Rome, pp. 9-22.

Fediuk, K., Hidiroglouw, N., Madère, R., and Kuhnlein, H. V. (2002). Vitamin C in Inuit Traditional Food and Women's Diets. Journal of Food Composition and Analysis 15: 221-235. https://doi.org/10. 1006/jfca.2002.1053.

Flint, C. G., Robinson, E. S., Kellogg, J., Ferguson, G., Boufajreldin, L., Dolan, M., Raskin, I., and Lila, M. A. (2011). Promoting Wellness in Alaskan Villages: Integrating Traditional Knowledge and Science of Wild Berries. EcoHealth 8(2): 199-209.

Ford, J. D., and Beaumier, M. (2011). Feeding the Family During Times of Stress: Experience and Determinants of Food Insecurity in an Inuit Community. Geographical Journal 177: 44-61. https://doi. org/10.1111/j.1475-4959.2010.00374.x.

Fraser, M. H., Cuerrier, A., Haddad, P. S., Arnason, J. T., Owen, P. L., and Johns, T. (2007). Medicinal Plants of Cree Communities (Québec, Canada): Antioxidant Activity of Plants Used to Treat Type 2 Diabetes Symptoms. Canadian Journal of Physioly and Pharmacology 85: 1200-1214.

Gérin-Lajoie, J. and Lévesque, E. 2011. Qarmaarjuit-Qinniqtut Historical Project. Final Report, Parks Canada, Iqaluit.

Gérin-Lajoie, J., Cuerrier, A., and Siegwart Collier, L. (2016). "The Caribou Taste Different Now". Inuit Elders Observe Climate Change, Nunavut Arctic College, Iqaluit.

Gubrium, J. F., Holstein, J., and Marvasti, A. (2012). The Sage Handbook of Interview Research: The Complexity of the Craft, 2nd edn., SAGE Publications, Los Angeles.

Harris, C. S., Cuerrier, A., Lamont, E., Haddad, P. S., Arnason, J. T., Bennett, S. A., and Johns, T. (2014). Investigating Wild Berries as a Dietary Approach to Reducing the Formation of Advanced Glycation Endproducts: Chemical Correlates of in Vitro Antiglycation Activity. Plant Foods for Human Nutrition 69(1): 71-77.

Henry, G. H. R., Harper, K. A., Chen, W., Deslippe, J. R., Grant, R. F., Lafleur, P. M., Lévesque, E., Siciliano, S. D., and Simard, S. W. (2012). Effects of observed and experimental climate change on terrestrial ecosystems of northern Canada: results from the Canadian IPY program. Climatic Change 115: 207-234.

Huet, C., Rosol, R., and Egeland, G. M. (2012). The Prevalence of Food Insecurity Is High and the Diet Quality Poor in Inuit Communities. Journal of Nutrition 142(3): 541-547. https://doi.org/10.3945/jn. 111.149278 .

Hupp, J. W., Safine, D. E., and Nielson, R. M. (2013). Response of Cackling Geese (Branta Hutchinsii Taverneri) to Spatial and Temporal Variation in the Production of Crowberries on the Alaska Peninsula. Polar Biology 36(9): 1243-1255. https://doi.org/ 10.1007/s00300-013-1343-3.

Joamie, A. and Ziegler, A. (2009). Walking with Aalasi: An Introduction to Edible and Medical Arctic Plants, Inhabit media, Iqaluit.

Karetak, J., Tester, F. and Tagalik, S. (2017). Inuit Qaujimajatuqangit. What Inuit Have Always Known To Be True, Fernwood Publishing, Black Point.
Karst, A. L., and Turner, N. J. (2011). Local Ecological Knowledge and Importance of Bakeapple (Rubus Chamaemorus L.) in a Southeast Labrador Métis Community. Ethnobiology Letters 2: 6-18.

Kellogg, J., Wang, J., Flint, C., Ribnicky, D., Kuhn, P., Gonzalez De Mejia, E., Raskin, I., and Lila, M. A. (2010). Alaskan Wild Berry Resources and Human Health under the Cloud of Climate Change. Journal of Agriculture and Food Chemistry 58: 3884-3900.

Kellogg, J., Higgs, C., and Lila, M. A. (2011). Prospects for Commercialisation of an Alaska Native Wild Resource as a Commodity Crop. Journal of Entrepreneurship 20(1): 77-101.

Kishigami, N. (2004). A New Typology of Food-Sharing Practices among Hunter-Gatherers, with a Special Focus on Inuit Examples. Journal of Anthropological Research 60(3): 341-358.

Koons, D. N., Rockwell, R. F., and Aubry, L. M. (2014). Effects of Exploitation on an Overabundant Species: The Lesser Snow Goose Predicament. Journal of Animal Ecology 83: 365-374. https://doi.org/10.1111/1365-2656.12133.

Krupnik, I. and Jolly, D. (2010). The Earth is Faster Now. Indigenous Observations of Arctic Environmental Change, ARCUS, Fairbanks.

Kugluktukmiut Elders and Youth, and Desrosiers, S. (2016). The Berry Book, Desrosier, S., Vancouver.

Kuhnlein, H. V., and Soueida, R. (1992). Use and Nutrient Composition of Traditional Baffin Inuit Foods. Journal of Food Composition and Analysis 4(3): 112-126.

Lavallée, C. (2013). Impact de l'augmentation du couvert ligneux érigé et d'un réchauffement expérimental sur la productivité d'Empetrum nigrum L., Vaccinium uliginosum L. et $V$. vitis-idaea L., à Kangiqsujuaq et Kangiqsualujjuaq (Nunavik), MSc thesis, Université du Québec à Trois-Rivières.

Loring, P. A., and Gerlach, S. C. (2009). Food, Culture, and Human Health in Alaska: An Integrative Health Approach to Food Security. Environmental Science \& Policy 12(4): 466-478. https:// doi.org/10.1016/j.envsci.2008.10.006.

Lussier, I. (2016). Impact de l'arbustation récente sur l'abondance et la productivité de Vaccinium uliginosum 1., Vaccinium vitis-idaea 1. et Empetrum nigrum à Umiujaq (Nunavik), MSc thesis, Université du Québec à Trois-Rivières.

Määttä-Riihinen, K. R., Kamal-Eldin, A., Mattila, P. H., GonzálezParamás, A. M., and Törrönen, A. R. (2004). Distribution and Contents of Phenolic Compounds in Eighteen Scandinavian Berry Species. Journal of Agricultural and Food Chemistry 52(14): 4477-4486.

Mathiassen, T. (1928). Material Culture of the Iglulik Eskimos, Gyldendal, Copenhagen.

Myers, H., Fast, H., Kislalioglu Berkes, M., and Berkes, F. (2005). Feeding the family in times of change. In Berkes, F., Fast, H., Manseau, M., and Diduck, A. (eds.), Breaking Ice: Renewable Resource and Ocean Management in the Canadian North, Univerity of Calgary Press, Calgary, pp. 23-47.

Myers-Smith, I. H., Elmendorf, S. C., Beck, P. S. A., Wilmking, M., Hallinger, M., Blok, D., Tape, K. D., Rayback, S. A., MaciasFauria, M., et al. (2015). Climate Sensitivity of Shrub Growth across the Tundra Biome. Nature Climate Change 5: 887-891. https://doi. org/10.1038/nclimate2697.

Nadasdy, P. (2007). The Gift in the Animal: The Ontology of Hunting and Human-Animal Sociality. American Ethnologist 34(1): 25-43.

Nancarrow, T. L. and Chan, H. M. (2010). Observations of Environmental Changes and Potential Dietary Impacts in Two Communities in Nunavut, Canada. Rural and Remote Health 10(2): $12 \mathrm{pp}$.

Ogawa, K., Sakakibara, H., Iwata, R., Ishii, T., Sato, T., Goda, T., Shimoi, K., and Kumazawa, S. (2008). Anthocyanin Composition and Antioxidant Activity of the Crowberry (Empetrum Nigrum) and Other Berries. Journal of Agricultural and Food Chemistry 56(12): $4457-4462$. 
Oostdam, J. V., Donaldson, S. G., Feeley, M., Arnold, D., Ayotte, P., Bondy, G., Chan, L., Dewaily, É., Furgal, C. M., et al. (2005). Human Health Implications of Environmental Contaminants in Arctic Canada: A Review. Science of the Total Environment 351352: 165-246. https://doi.org/10.1016/j.scitotenv.2005.03.034.

Ootoova, I., Atagutsiak, T. Q., Ijjangiaq, T., Pitseolak, J., Joamie, A., Joamie, A. and Papatsie, M. (2001). Perspectives on Traditional Health, Language and Culture Program of Nunavut Arctic College, Iqaluit.

Oswalt, W. H. (1957). A Western Eskimo Ethnobotany. Anthropological papers of the University of Alaska 6(1): 16-36.

Parlee, B., and Berkes, F. (2005). Health of the Land, Health of the People: A Case Study on Gwich'in Berry Harvesting in Northern Canada. EcoHealth 2: 127-137.

Parlee, B., and Berkes, F. (2006). Indigenous Knowledge of Ecological Variability and Commons Management: A Case Study on Berry Harvesting from Northern Canada. Human Ecology 34: 515-528.

Porsild, A. E. (1953). Edible Plants of the Arctic. Arctic 6(1): 15-34.

Porsild, A. E. and Cody, W. J. (1980). Vascular Plants of the Continental Northwest Territories, Canada, National Museum of Canada, Ottawa.

Prno, J., Bradshaw, B., Wandel, J., Pearce, T., Smit, B., and Tozer, L. (2011). Community Vulnerability to Climate Change in the Context of Other Exposure-Sensitivities in Kugluktuk, Nunavut. Polar Research 30: 21. https://doi.org/10.3402/polar.v30i0.7363.

QGIS Development Team (2017). QGIS Geographic Information System. Open Source Geospatial Foundation Project. http://www. qgis.org. Accesssed July 2017

QSR International Pty Ltd. (2016). NVivo qualitative data analysis Software, Version 11.

Rapinski, M., Payette, F., Sonnentag, O., Herrmann, T. M., Royer, M.-J. S., Cuerrier, A., Siegwart Collier, L., Hermanutz, L., Guanish, G. et al. (2018a). Listening to Inuit and Naskapi Peoples in the Eastern Canadian Subarctic: A Quantitative Comparison of Local Observations with Gridded Climate Data. Regional Environmental Change 1-15. https://doi.org/10.1007/s10113-017-1188-3.

Rapinski, M., Cuerrier, A., Lemire, M., and Harris, C. (2018b). Inuit perception of marine organisms: from folk classification to food harvest. Journal of Ethnobiology. 38(3): 333-355.

Searles, E. (2002). Food and the Making of Modern Inuit Identities. Food and Foodways 10: 55-78.

Searles, E. (2016). To sell or not to sell: country food markets and Inuit identity in Nunavut. Food and Foodways 24: 194-212.
Simard-Gagnon, L. (2013). Vivre et manger le territoire: la gestion des petits fruits par les femmes inuites en contexte contemporain, MA thesis, Université Laval.

Stefansson, V. (1914). The Stefasson-Anderson Arctic Expedition of the American Museum: Preliminary Ethnological Report, Order of the Trustees, New York.

Stefansson, V. (1922). My Life with the Eskimo, Macmillan, New York.

Taruscio, T. G., Barney, D. L., and Exon, J. (2004). Content and Profile of Flavanoid and Phenolic Acid Compounds in Conjunction with the Antioxidant Capacity for a Variety of Northwest Vaccinium Berries. Journal of agricultural and food chemistry 52(10): 3169-3176.

Tester, F. J., and Kulchyski, P. (1994). Tammarniit (Mistakes): Inuit Relocation in the Eastern Arctic, 1939-1963, UBC Press, Vancouver.

Thornton, T. F. (1999). Tleikw Aan1, the "Berried" Landscape: The Structure of Tlingit Edible Fruit Resources at Glacier Bay, Alaska. Journal of Ethnobotany 19: 27-48.

Tremblay, B., Lévesque, E., and Boudreau, S. (2012). Recent Expansion of Erect Shrubs in the Low Arctic: Evidence from Eastern Nunavik. Environmental Research Letters 7(035501): 11. https://doi.org/10. 1088/1748-9326/7/3/035501.

Turner, N. J. (2005). The Earth's Blanket: Traditional Teachings for Sustainable Living, Douglas \& McIntyre, Madeira Park.

Turner, N. J., and Davis, A. (1993). "When Everything Was Scarce": The Role of Plants as Famine Foods. Journal of Ethnobiology 13(2): 171-201.

Turner, N. J., and Turner, K. L. (2008). "Where Our Women Used to Get the Food": Cumulative Effects and Loss of Ethnobotanical Knowledge and Practice; Case Study from Coastal British Columbia. Botany 86(2): 103-115.

Turner, N. J., Deur, D., and Mellott, C. R. (2011). "Up on the Mountain": Ethnobotanical Importance of Montane Sites in Pacific Coastal North America. Journal of Ethnobiology 31(1): 4-43.

Walker, D. A., Raynolds, M. K., Daniëls, F. J. A., Einarsson, E., Elvebakk, A., Gould, W. A., Katenin, A. E., Kholod, S. S., Markon, K. J., et al. (2005). The Circumpolar Arctic Vegetation Map. Journal of Vegetation Science 16: 267-282. https://doi.org/ 10.1111/j.1654-1103.2005.tb02365.x.

Watson, A., and Huntington, O. H. (2008). They're Here-I Can Feel Them: The Epistemic Spaces of Indigenous and Western Knowledges. Social \& Cultural Geography 9(3): 257-281.

Zutter, C. (2009). Paleoethnobotanical Contributions to 18th-Century Inuit Economy: An Example from Uivak, Labrador. Journal of the North Atlantic 2(1): 23-32. 